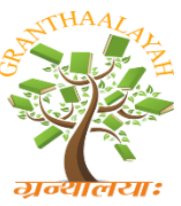

INTERNATIONAL JOURNAL OF RESEARCH GRANTHAALAYAH A knowledge Repository

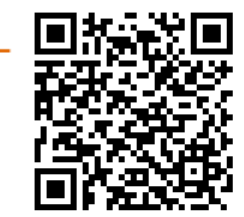

Social

\title{
SCHOLASTIC ACHIEVEMENT IN ENGLISH BETWEEN TUTEE AND NON-TUTEE STUDENTS AT SECONDARY LEVEL
}

\author{
M.Keerthana ${ }^{1}$, J.Justin Jebaraj ${ }^{2}$ \\ ${ }^{* 1}$ M.Ed Scholar, RVS College of Education, India \\ ${ }^{2}$ Assistant Professor, RVS College of Education, India
}

DOI: https://doi.org/10.29121/granthaalayah.v5.i5(SE).2017.1983

\begin{abstract}
The paper is an attempt to find the scholastic achievement in English between tutee and non tutee students at secondary level. In the present study experimental method was used. The investigator adopted the experimental method to study the scholastic achievement in English between tutee and non tutee students at secondary level Investigator selected only students at secondary level and 50 students as sample in Coimbatore district using stratified random sampling. The findings reveal that there is a mild positive relationship between social intelligence and academic achievement among the selected arts group students at Higher Secondary level.
\end{abstract}

Keywords: Scholastic Achievement; English; Tutee; Academic; Intelligence.

Cite This Article: M.Keerthana, and J.Justin Jebaraj. (2017). "SCHOLASTIC ACHIEVEMENT IN ENGLISH BETWEEN TUTEE AND NON-TUTEE STUDENTS AT SECONDARY LEVEL." International Journal of Research - Granthaalayah, 5(5)SE, 127-131. https://doi.org/10.29121/granthaalayah.v5.i5(SE).2017.1983.

\section{Introduction}

A tutee is the individual who is receiving the tutoring. In a utopian reality, every student would be capable of going from his or her first day of school right into their high school or college graduation without any hesitation or bumps in what would become their chosen educational path. All students would be completely prepared, competent, and analogous to handle the rigors of standardized academia as they enter the school building for the first time. All students are not adequately prepared, skilled, or analogous to trudge on through school processing the multitude of information presented to them in the traditional classroom setting. The school house cannot be a place in which students sit and absorb knowledge from a lecturing teacher because students and their learning styles are as individual as snowflakes. Therefore, we need to facilitate learning through many different approaches. One of the most common and time tested methods is some variation of a formal or informal peer tutoring program. 
The benefits of a successful peer tutoring program will clearly outweigh the drawbacks of the program or the program would definitely cease to exist. The well-known benefits to peer tutoring are the increased academic gains and social enhancement outcomes of the peer tutoring program. According to Santee and Garavalia (2006), some benefits to the tutee include working with someone who they relate to, an increased enthusiasm for learning, and an increased comfort level for performance related discussions. They go on to say that benefits to the tutors may be as valuable and can include the reinforcement of skills, gain a broader understanding of the subject area, and increase their confidence levels. Research has found peer tutoring can provide more than twice as much achievement than computer aided instruction, three times more than reducing class size, and almost four times more than lengthening the school day (Jenkins, 2002, p. 65). Another significant outcome of peer tutoring is the relationship that develops between the tutor and tutee which can be reinforced when they feel they are working toward a commonly defined goal (Vogel, Fresko, \& Wertheim, 2007, p. 486).

\section{Method}

The investigator adopted the experimental method to study the scholastic achievement in English between tutee and non tutee students at secondary level Investigator selected only students at secondary level and 50 students as sample in Coimbatore district using stratified random sampling. Out of 50 students 25 students belong to control group and 25 students belong to experimental group.

\section{Hypothesis: 1}

There is no significant mean score difference between pre-test and post-test of the Control group on the scholastic achievement in English among students at secondary level.

Table 1: Significance of the Mean Score Difference in Pre-Test and Post-Test Scores of Control Group Students

\begin{tabular}{|c|c|c|c|c|c|c|}
\hline $\begin{array}{l}\text { CONTROL } \\
\text { GROUP }\end{array}$ & $\mathbf{N}$ & MEAN & $\begin{array}{l}\text { STANDARD } \\
\text { DEVIATION }\end{array}$ & DF & T-VALUE & $\begin{array}{l}\text { LEVEL OF } \\
\text { SIGNIFICANCE AT } \\
\text { 0.005 LEVEL }\end{array}$ \\
\hline PRE TEST & 25 & 27.08 & 4.830 & \multirow[b]{2}{*}{24} & \multirow[b]{2}{*}{-7.996} & \multirow[b]{2}{*}{.000} \\
\hline POST TEST & 25 & 30.40 & 4.163 & & & \\
\hline
\end{tabular}

The pre-test of control group have 25 students. Their mean score is 27.08 and the standard deviation is 4.830 similarly, the post-test of control group have 25 students. Their mean score is 30.40 and the standard deviation is 4.163 . The calculated t-value is -7996 . This is significant at 0.00 level. Hence, hypothesis 1 is rejected. This reveals that there is significant mean score difference between pre-test and post-test of the Control group on the scholastic achievement in English among students at secondary level. 


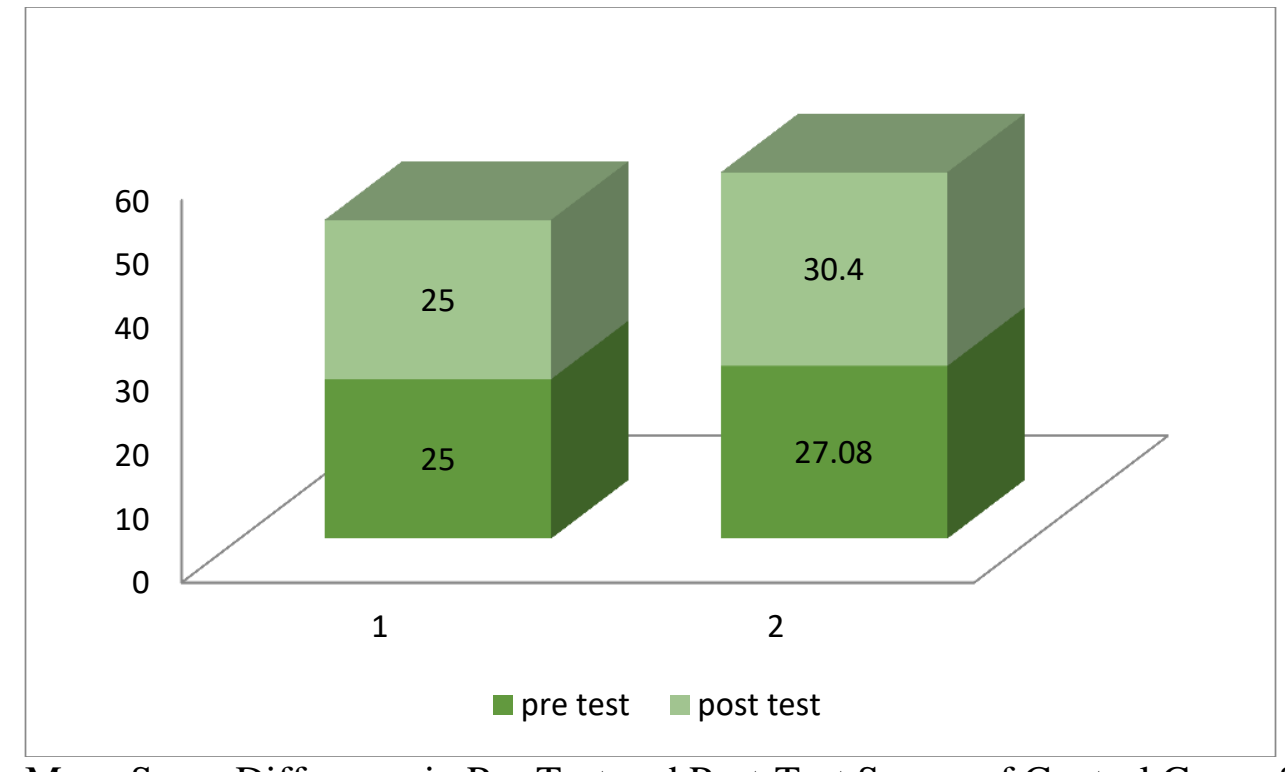

Chart 1: Mean Score Difference in Pre-Test and Post-Test Scores of Control Group Students

\section{Hypothesis: 2}

There is no significant mean score difference between pre-test and post-test of the experimental group on the scholastic achievement in English among students at secondary level.

Table 2: Significance of the Mean Score Difference in Pre-Test and Post-Test Scores of

\begin{tabular}{|l|l|l|l|l|l|l|}
\hline $\begin{array}{l}\text { CONTROL } \\
\text { GROUP }\end{array}$ & $\mathbf{N}$ & MEAN & $\begin{array}{l}\text { STANDARD } \\
\text { DEVIATION }\end{array}$ & DF & T-VALUE & $\begin{array}{l}\text { LEVEL OF O.005 LEVEL } \\
\text { SIGNIFICANCE } \\
\text { AT 0.05 }\end{array}$ \\
\hline PRE TEST & $\mathbf{2 5}$ & 34.20 & 5.715 & & & \\
\hline POST TEST & $\mathbf{2 5}$ & 38.32 & 5.121 & $\mathbf{2 4}$ & -5.801 & $\mathbf{. 0 0 0}$ \\
\hline
\end{tabular}

The pre-test of experimental group have 25 students. Their mean score is 34.20 and the standard deviation is 5.715 Similarly, the post-test of experimental group have 25 students. Their mean score is 38.32 and the standard deviation is 5.121. The calculated t-value is -5.801 . This is significant at 0.00 level. Hence, hypothesis 2 is rejected. This reveals that there is a significant mean score difference between pre-test and post-test of the experimental group on the scholastic achievement in English among students at secondary level. 


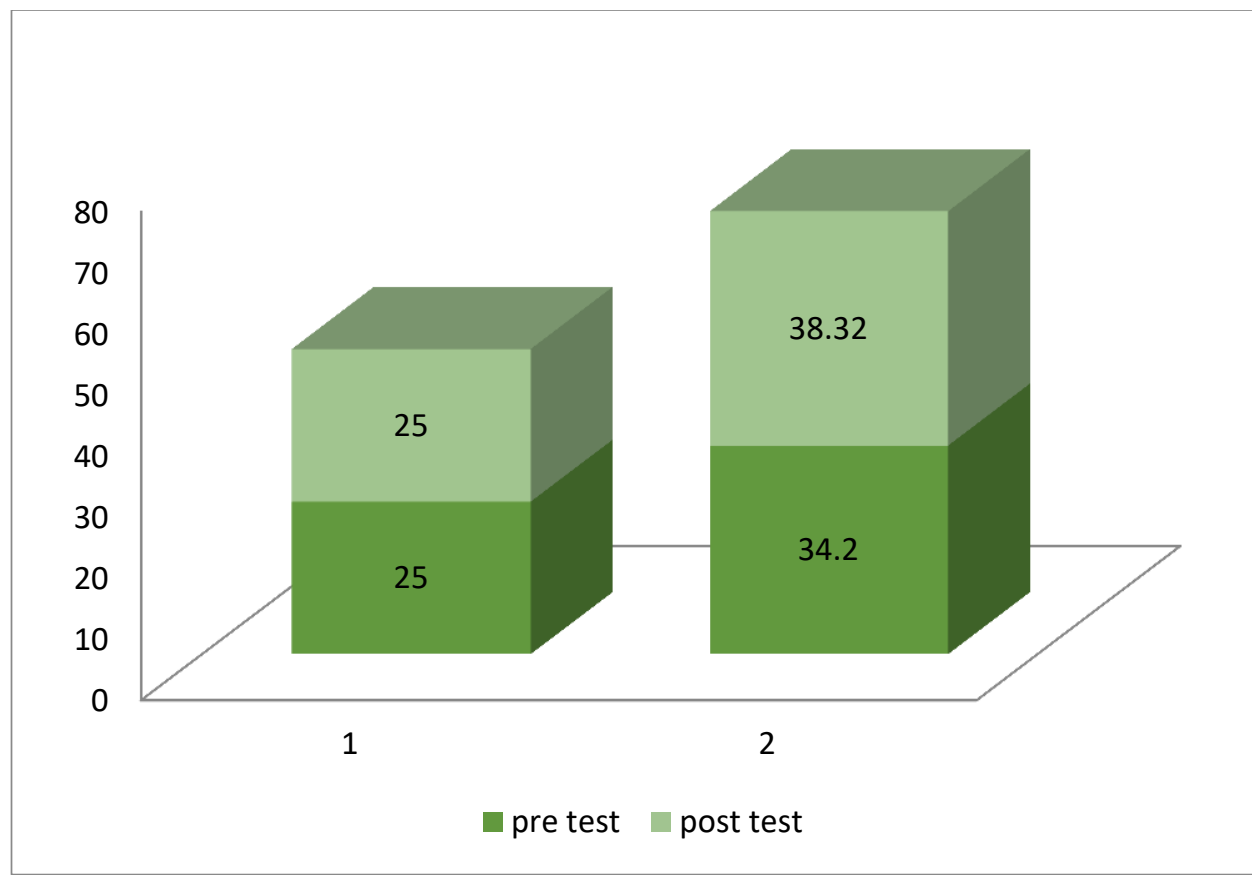

Chart 2: Mean Score Difference in Pre-Test and Post-Test Scores of Experimental Group Students

\section{HYPOTHESIS 3:}

There is no significant mean score difference between Control group and Experimental Group of gain scores on the scholastic achievement in English among students at secondary level.

Table 3: Significance of the Mean Score Difference in Gain Scores of Control Group and Experimental Group Students

\begin{tabular}{|l|l|l|l|l|l|l|}
\hline $\begin{array}{l}\text { CONTROL } \\
\text { GROUP }\end{array}$ & $\mathbf{N}$ & MEAN & $\begin{array}{l}\text { STANDARD } \\
\text { DEVIATION }\end{array}$ & DF & $\begin{array}{l}\text { T- } \\
\text { VALUE }\end{array}$ & $\begin{array}{l}\text { LEVEL OENIFICANCE } \\
\text { AT } \\
\text { LEVEL }\end{array}$ \\
\hline $\begin{array}{l}\text { CONTROL GROUP } \\
\text { GAIN SCORE }\end{array}$ & $\mathbf{2 5}$ & 3.32 & 2.076 & $\mathbf{2 4}$ & & \\
\hline $\begin{array}{l}\text { EXPERIMENTAL } \\
\text { GROUP GAIN } \\
\text { SCORE }\end{array}$ & $\mathbf{2 5}$ & 4.12 & 3.551 & & -.956 & .349 \\
\hline
\end{tabular}

The mean gain score of control group is 3.32 and the standard deviation is 2.076. Similarly, the mean gain score of Experimental group is 4.12. The calculated t-value is -956 . This is not significant at 0.05 level. Hence, hypothesis 3 is rejected. This reveals that there is a significant mean score difference between the gain scores of Control group and Experimental Group on the scholastic achievement in English among students at secondary level. 


\section{Conclusion}

The findings reveal that there is a significant mean score difference between pre-test and posttest of the Control group on the scholastic achievement in English. Also There is a significant mean score difference between pre-test and post-test of the experimental group on the scholastic achievement in English among students at secondary level. And There is significant mean score difference between Control group and Experimental Group of gain scores on the scholastic achievement in English between tutee and non tutee students at secondary level.

\section{References}

[1] Abbott, M., Greenwood, C. R., Buzhardt, J., \& Tapia, Y. (2006). Using Technology-Based Teacher Support Tools to Scale up the ClassWide Peer Tutoring Program. Reading \& Writing Quarterly, 22(1), 47-64. doi:10.1080/10573560500203525.

[2] Council for Exceptional Children. (1988). Peer Tutoring and Small Group Instruction, Research Resources on Special Education. Retrieved on November 12, 2011 from www.eric.ed.gov/ERICWebPortal/recordDetail?accno=ED377639

[3] Dabkowski, Brendon. (2000). The History of Peer Tutoring. Intertext: A Student Publication of the Syracuse University Writing Program. Retrieved on October 29, 2011 from http://wrtintertext.syr.edu/viii/dabkowski.html

[4] Golden, S. A. R. (2011). Problems and Prospectus of Distance Learning. Bharathidhasan University, 343, 344.

[5] Golden, S. A. R. (2016). RURAL STUDENTS'ATTITUDE TOWARDS ENGLISH AS MEDIUM OF INSTRUCTION IN HIGHER EDUCATION-AN ANALYSIS. International Journal of Research, 3, 1-10.

[6] Golden, S. A. R. (2017). Attitude of Students and Teachers towards E-Learning-An Analysis. Recent Research in Social Science \& Humanities, 1, 5-10.

[7] Maheady, L., Mallette, B., \& Harper, G. F. (2006). Four Classwide Peer Tutoring Models: Similarities, Differences, and Implications for Research and Practice. Reading \& Writing Quarterly, 22(1), 65-89. doi:10.1080/10573560500203541

[8] Regi, S. B., \& Golden, S. A. R. (2014). A Study On Educational Loan Availed By Students In Trichy City. Journal Of International Academic Research For Multidisciplinary (Jiarm), 2 (1).

[9] Santee, J., \& Garavalia, L. (2006). Peer Tutoring Programs in Health Professions Schools. American Journal of Pharmaceutical Education, 70(3), 1-10. Retrieved from EBSCOhost. 